\title{
John, duke of Bedford's arrangements for the defence of Normandy in October 1434 : College of Arms MS Arundel 48, folios 274r-276v.
}

\author{
AnNe CURRY*
}

\begin{abstract}
He EngLish presence in Normandy in the early fifteenth century (14171450) was sustained by garrisons installed in the key towns and castles. L For the most part, this followed French precedents but the number of soldiers maintained by the English was necessarily larger. That said, the size of English garrisons in the duchy fluctuated in response to the state of the war. We can see, for instance, that it was reduced following the English victory at Verneuil (1424) from circa 4500 to 3200 men, and but subsequently reinforced to circa 4000 following the successes of Charles VII and Joan of Arc in $1429-1430^{1}$. It is possible to reconstruct the size of the garrisons by drawing on surviving financial records from the chambre des comptes for the period of English rule. In some years we have a virtually complete picture thanks to the survival of the account books of the receiver general of Normandy ${ }^{2}$. For most years, we have to rely on the random survival of indentures (endentures) entered into by garrison captains, quarterly musters of their troops (montres), and quarterly receipts for the pay which they collected on behalf of their men (quittances). Whilst much documentation survives, it is not possible to know the size of every garrison.
\end{abstract}

We are fortunate, however, that five documents exist which provide a complete listing of all the garrisons at various points in time. The best known, since it has been easily accessible in print since 1864, relates to the year 1433 to $1434^{3}$. It is amongst the many materials from Lambeth Palace MS 506 which Joseph Stevenson included in his compilations in the Rolls Series ${ }^{4}$. This manuscript is

\footnotetext{
* University of Southampton.

1 A. Curry, "English Armies in the Fifteenth Century ", Armies, Armies and Fortifications in the Hundred Years War, A. Curry et M. Hughes (ed.), Woodbridge, The Boydell Press, 1994, p. 48-60.

2 For example, for 1423-5 and 1428-9: BNF manuscrit français, 4485, 4488.

3 J. Stevenson, Letters and Papers Illustrative of the Wars of the English in France during the reign of Henry the Sixth, King of England, Rolls Series, 2 vols, London, Longman, 1861-1864, p. 540-546.

4 London, Lambeth Palace MS 506, fol. 16v-20r.
} 
a compilation of materials relating to Lancastrian Normandy made by William Worcestre (alias Botoner), secretary to Sir John Fastolf, one of the most famous English captains of the period ${ }^{5}$. The list, given in Latin, is headed :

Declaratio hominum armorum, lanceorum et sagittariorum existentium in castris, fortalitiis, munitionibus, civitatibus et villis in ducatus Normaniae et patriae conquaesta pro salva custodia et defensione eorumdem a festo Sancti Michaelis anno Christi $m$ iiij c xxxiij usque dictum festum Michaelis anno Christis m iiijc xxxiiij ex ordinatione domini regentis regni Franciae Johannis ducis Bedfordiae et per concilium Regis apud castrum de Falloise facta

It seems therefore to be a copy made by Worcestre of a list which had been drawn up in 1433-1434, the original of which is now lost. It lists 50 garrisons and retinues. In all, 43 different locations can be seen to have housed a garrison. In one of these, Rouen, the separate garrisons for the town, gates and walls, castle and bridge are noted. Three of the 43, Gisors, Gournay and Neufchâtel are grouped together under the entry for Gisors. The numbers of soldiers are given save in the case of Montivilliers which was held for a lump sum payment of 300 livres tournois by Clement Overton ${ }^{6}$. The list includes five retinues not based in garrison, totalling 125 men. These are the companies of the treasurer and the receiver-general of the duchy, the controller of the receipt, the master of the ordnance, and of the earl Arundel as lieutenant for the field. At the end of the list, the totals of mounted and foot lances (meaning here individual men-at-arms) and of archers are given (as 367, 489 and 2415 respectively) along with a calculation of the cost of their wages for one year. This gives a total of 3271 men held by the English in Normandy, but adding the individual entries together with the aid of a calculator actually gives 3.186 soldiers.

A second list of English garrisons and retinues is also in print. The original document is also in Lambeth Palace MS 506 (folios 28r-30r) but was not included by Stevenson in his compilation published in the Rolls Series. The version in print is to be found in the Journal des Savants de Normandie for 1844. This is taken from a sixteenth-century copy in the archives of the Matignon family. The list is in Latin and headed :

5 K.B. McFarlane, «William Worcestre: A Preliminary Survey », Studies Presented to Sir Hilary Jenkinson, Oxford, Clarendon Press, 1957, p. 196-221, reprinted in K.B. McFarlane, England in the Fifteenth Century. Collected Essays, Gerald Harriss (ed.), London, The Hambledon Press, 1981, p. 199-224.

6 As the baillis were customarily also captain of a garrison, the retinues for their office are sometimes included within the numbers for the garrison they commanded (as at Arques for the bailli of Caux, and Essay for the bailli of Alençon,). The retinue of the bailli of Mantes is listed under Mantes but a separate number given for the official retinue. The retinues of the baillis of Caen and of Rouen are given as discrete entries.

7 F. Dubosc, « Manuscrit inédit tire des archives de la maison de Matignon », Journal des Savants de Normandie, Rouen, 1844, p. 33-51. The Matignon archive also contained copies of other documents 
Declaratio gentium armorum, architenentium, tam equestrium quam pedestrium, existentium in vadiis, retentorum en les garnisons [sic] castris et fortalitiis ducatus Normannie pro salva custodia eorum et ad serviendum in campis cum necesse fuerit et fuit ordinaum sub temporare inclyti principis domini gubernantis regni Francie, Ricardi ducis de York, tempore et anno quo treuga velut pax tractate est et apuncutuata fuit inter Henricum vj regem Anglie et Francie et Carolum vij Francorum regem.

It names 43 places holding troops although these are not identical to those of 1433. On this occasion Gerberoy is joined with Gournay, Elbeuf with Pont de-Arche, and Longny with Verneuil. Rouen now has separate retinues for the town, castle, bridge, palace and monastery of St Katherine. In some cases the garrison size consists of a company for service in the field as well as troops for garrison defence. No names of captains are provided but for each place (or group) the numbers of troops are given. The total in garrison is given as 196 mounted men-at-arms, 436 foot and 1890 archers, i.e. 2 522, but by adding the entries with a calculator we come to 2542 . In addition nine other personal and official retinues are listed after the garrison totals are given. These are totalled as 38 men-at-arms and 200 archers but adding the entries gives 34 men-at-arms and 180 archers. We therefore have a grand total of 2760 , or 2756 by calculation. This list reflects the reduction in garrisons following the truce of Tours of May 1444.

Three further lists, all in French, remain unpublished. Two date to 1436 and survive in as originals in the series « quittances et pièces diverses » within the manuscrits français of the Bibliothèque Nationale. One provides the sizes of garrisons in 36 locations in Normandy between 30 March and 1 July $1436^{8}$, the second of 35 locations in the following quarter, 29 June to 1 October $1436^{9}$. Both also include seven personal and official retinues. No captains are named but the numbers of mounted and foot lances, and of archers are given for each place or company. No totals are given in the documents but adding the entries gives 5884 and 5309 men respectively. A further reference elsewhere suggests that a 'rôle des garnisons' was drawn up for the quarter between December 1435 and March 1436 but this list does not appear to survive ${ }^{10}$.

The third unpublished list in French is to be found in the College of Arms in London within MS Arundel 48 (folios 274r-276v). The list is headed :

which are also in Lambeth Palace MS 506. These included the declaration of the garrisons for 1433-1434, which was also printed in the same issue of the Journal des Savants but dated to 1434-1435.

$8 \mathrm{BnF}$, manuscrit français 25773/1071. No garrisons are grouped together, but for Rouen separate retinues are given for the town, castle and bridge.

$9 \mathrm{BnF}$, manuscrit français 25773/1112, transcribed in Anne E. Marshall, «The Role of English War Captains in England and Normandy 1436-1461 », unpublished MA dissertation, University of Wales (Swansea), 1975, p. 282-284. Bacqueville appears in the earlier but not the later list. It was not a location regularly garrisoned by the English.

$10 \mathrm{BnF}$, manuscrit français 26061/2995. 
Ce sont les endentures des garnisons de Normandie et pais de conquest advisees et faictes a Rouen ou mois doctobre mil iiij ${ }^{\mathrm{c}}$ xxxiiij par monsieur le Regent estant pour lors audit lieu

This document lists 55 garrisons and retinues, giving their current and previous size as well as the name of their captain. Forty-five places can be seen to house garrisons at this point. There is no summation of the total troop numbers at the end. By adding the various entries, we can see that the previous total size was 3188 men and the current size 4527 men. Of these 1.628 were companies housed in certain garrisons but with the intention that they should serve in the field as necessary (" pour les champs »). This means that the regular garrisons and retinues were intended to total 2899 men.

The list is in a French hand of the period but we cannot be certain that was drawn up contemporaneously. College of Arms MS Arundel 48 is a compilation of materials assembled by William Worcestre relating to the politics and chivalric culture of the recent past ${ }^{11}$. As English fortunes waned, Fastolf, Worcestre and others consciously recalled the glorious days of the good duke of Bedford ${ }^{12}$. The list may therefore be a copy of a lost original, or else a reminiscence of the events which had taken place in October 1434. The folios on which the list appears are paper rather than parchment. This is suggestive of a later copy since the chambre des comptes under English rule regularly used parchment, as can be seen in the surviving lists for 1436 in the Bibliothèque Nationale. The watermarks on folios 274 and 275 suggest a date in the 1440s or $1450 \mathrm{~s}^{13}$.

The two lists for 1436 are in the same format and date to the period they describe. This suggests that they were drawn up as an official initiative to record and inform military planning. The other three lists are all later copies. We cannot be certain, therefore, that an enumeration of the garrisons was compiled each year during the English tenure of Normandy, although such a practice would make sense. This paper concentrates solely on the list in the

11 The manuscript was later owned by members of the Hungerford family. Catalogue of the Arundel manuscripts in the library of the College of Arms, London, 1829, p. 74. See also A Catalogue of Manuscripts in the College of Arms: Collections, volume 1, London, 1988. The Records and Collections of the College of Arms, by Sir Anthony Richard Wagner, London, 1952, gives an excellent account of the history and extent of the archives of the College of Arms as a whole.

12 See C.T. Allmand, "France-Angleterre à la fin de la guerre de Cent ans : le Boke of Noblesse de William Worcester", dans La "France Anglaise" au Moyen Age. Actes du $111^{e}$ Congrès National des Sociétés Savantes (Poitiers, 1986), Section d'histoire médiévale et de philologie, t. 1, Paris, CTHS, 1988, p. 103-112.

13 Folio 274, a boar; folio 275 that of an anchor/crossbow. There is no watermark discernible on folio 276. For a complete listing of contemporary watermarks see C.M. BRiQUET, Les filigranes, A. Stevenson (ed.), Amsterdam, 1968. See E. Heawood, «Sources of Early English Paper-Supply », Transactions of the Bibliographical Society, series 2, vol. 10, The Library, 1929, p. 286 for a similar anchor/crossbow mark in a Paston Letter of 1457 and in the St Andrews Letter Book of 1440 and 1443. This suggests paper from the Troyes region. See also V. Mosin, Anchor Watermarks, Amsterdam, 1973, p. 7. 
College of Arms, providing a transcription. I am delighted to have the opportunity to present it in celebration of the contribution of Catherine Bougy to the history and culture of Normandy in the Middle Ages.

\section{Context}

Although the English had been able to stabilise their position after the crises of 1429-30, the subsequent years were stagnant in military terms. The main aim of John, duke of Bedford, who continued to control his nephew's interests in France, focused on maintaining the status quo. Financial difficulties increased, particularly as a result of the siege of Lagny-sur-Marne (April-July 1432) which proved an expensive failure despite Anglo-Burgundian military cooperation. It was also a blow to Bedford's military reputation as it was the first time he had taken the field since 1424. Monies intended for the payment of the Norman garrisons for the period between March and September 1432 had been diverted to the costs of the siege. Arrears of garrison wages could only be paid when Bedford received additional revenues from England ${ }^{14}$. By this stage Bedford was increasingly dependent upon financial support and expeditionary armies sent from England. It was to seek further assistance, and to answer the increasingly vociferous critics of his military policies, that the duke returned to England in June 1433. In the following month he made a declaration before parliament challenging his critics to make public their accusations on neglect and mismanagement in Normandy. Although in November the Commons in Parliament reassured him of their respect for his reputation they made no practical offer of help for the war effort, beseeching him rather to stay in England. Therefore new ideas had to be devised on how men and money could be found ${ }^{15}$.

In the spring of 1434 Bedford put proposals to the royal council which were aimed at providing a regular army for the field under his own control, thereby making him less dependent upon expeditionary armies from England ${ }^{16}$. The funding of this field army would be achieved, Bedford proposed, by releasing some of the revenues of the duchy of Lancaster assigned for the execution of Henry V's will. These revenues, it was suggested, would provide for an annual contingent from England of 800 men. Secondly a further 800 men would be available for service in Normandy " in case of sodern necessitee or behove » and as an escort for Bedford himself, from troops which he would place in the Calais March which was to be placed under his control. Thirdly, additional

14 BnF, Clairambault 156/159.

15 For discussion of the events of Bedford's visit to England see R.A. Griffiths, The Reign of Henry VI, Tonbridge and London, 1981, p. 196-198, and J. BArker, Conquest. The English Kingdom of France 1417-1450, London, 2009, p. 203-207.

16 H. Nicolas (ed), Proceedings of the Privy Council of England, vol. IV, p. 222-232. 
finances would be provided by Bedford himself forgoing for two years some of his own revenues in Normandy. These proposals were aimed at ensuring military strength but also reducing the burden on English taxpayers « in such wyse that hit shal not greatly charge your subgettes of this reaume so that it lyke our lord to kepe your people there from sodein aventure ».

In this context we also see evidence of the rivalry between Bedford and his younger brother, Humphrey, duke of Gloucester, who oversaw the government of England during Henry VI's minority. Gloucester had his own more ambitious and aggressive ideas on how the war should be conducted. Bedford's more conservative, cost-cutting plans were, not surprisingly, more persuasive and gained approval from the council and parliament.

Surviving documentation reflects the preparation of information to inform these debates during Bedford's time in England. We have the estimate presented to the Parliament by the then Treasurer of England, Ralph, Lord Cromwell ${ }^{17}$. This made clear the scale of the financial pressures on the English government. We also have a number of documents which estimate income and expenditure within Normandy and Maine covering the financial year 1433-1434. These survive as later copies in Lambeth MS 506, but the originals appear to have been commissioned by Bedford to inform discussions of possible future financial and military arrangements in Normandy. For instance, a statement was drawn up at Caen on 23 December 1433 of the anticipated profits and costs of the duchy ${ }^{18}$. There is also an assessment of Bedford's own financial position in his landholdings, the counties of Harcourt and Dreux, which can be linked to his offer to forgo some of his revenues ${ }^{19}$. It was probably in this context that the declaration of the garrisons for 1433-1434, in Lambeth Palace MS 506, was produced ${ }^{20}$. A comparison with the surviving quittances for garrison captains shows that it was an accurate summary of the captains and numbers in garrison after Michaelmas 1433.

What the list of the garrisons in College of Arms MS Arundel 48 demonstrates is how Bedford undertook a reform of garrison organisation following his return to France in July $1434^{21}$. This was an integral part of his broader plan to ensure sound military defence in Normandy and to facilitate the provision of troops for the field, whilst operating within an agreed financial budget. Bed-

17 A. Curry (ed.), Parliament Rolls of Medieval England, 1275-1504. XI. Henry VI, 1432-1445, Woodbridge, 2005, p. 102-13.

18 J. Stevenson, Letters and Papers..., op. cit., II, ii, p. 547-8

19 Ibid., p. 553-9.

20 Lambeth MS 506 ff. 22v-23r also contains a list of the garrisons of Maine and their costs, printed in Stevenson, Letters and Papers..., op. cit., II, ii, p. 551-2.

21 For the reforms in general see R.A. Newhall, Muster and Review, A Problem of English Military Administration, Cambridge, Mass., 1940, p. 118-120. 
ford was in Rouen by at least 12 September $1434^{22}$. Between 18 and 30 September he and his council held a «parliamentum... pro gubernatione ducatus Normannie » in the Norman capital to which the duchy's towns sent representatives. Interestingly, one of the representatives was Perceval de Gaillartbois, a Norman who also served as a foot man-at-arms in the garrison of Château Gaillard $^{23}$. It is possible that the subsequent defensive provision revealed in the MS Arundel 48 list was proposed and discussed at this assembly. It was common under English rule for such local consultation to take place.

By 20 October 1434 new indentures had been prepared for all of the garrison captains in Normandy and in the 'pays de conquête' (i.e. the area to the east of Normandy containing places captured by Henry $V$ which was subsequently administered in military terms along with the duchy). Several of these survive and others are known through references in orders to pay wages and in quittances ${ }^{24}$. All were issued in Bedford's name, save for those of his own captaincies which were issued in the name of the king. The indentures were in a standard format which followed that established in 1430 during the royal visit but introduced some important new clauses. They were all valid for two years retrospectively from Michaelmas 1434, a change from the customary one-year appointments. Secondly they changed the restrictions on recruitment of native soldiers : one-eighth of the whole retinue, both men-at-arms and archers, were permitted to be French. The « reserved occupations »of « hoteliers » and « taverniers " were added to those of nobles, householders, craftsmen and merchants. In addition, men involved in a recent affray at St Pierre-sur-Dives were specifically banned from recruitment into garrison service. The incident exemplified the problems of military indiscipline which had mounted during Bedford's absence. In this context it is significant that the indentures gave Bedford increased powers over the captains of garrisons. If they committed any defaults, they could be removed from office or replaced at will.

The indentures drawn up on 20 October indicate that captains were instructed to maintain their existing numbers until 1 November when new numbers should come into effect. For instance, Bedford himself was retained for two years as captain of Alençon ${ }^{25}$. To 1 November he was to hold the same numbers as the previous year (26 mounted men-at-arms, 14 foot and 120 archers), and after that date 43 mounted men-at-arms, 21 foot men-atarms, 129 mounted archers and 63 foot archers. Of these, 40 men-at-arms and 120 archers, all mounted, were to be for the field, leaving 3 mounted men-at-arms, 21 foot men-at-arms and 9 mounted archers and 63 foot archers

22 BnF, manuscrit français $26427 / 33$.

$23 \mathrm{BnF}$, manuscrit français $26058 / 2314$.

24 See, for instance, a series of indentures in BnF, manuscrit français 26058/2370-85.

25 He had held the captaincy since 12 February 1431 (Archives Nationales de France 63/10/75), and he remained in office until his death (Oxford, Bodleian Library MS Charter Foreign 324). 
for the regular garrison ${ }^{26}$. The numbers in Bedford's indenture match exactly those in the list. Evidence suggests that there was a short delay in effecting the changes. On 6 November the garrison of Alençon mustered at its old strength. On 16 November two separate musters were taken, of the regular garrison at the intended new size of 96 men, and of the field company (called the " creu ", meaning additional) at 40 men-at-arms and 113 archers of the 160 men intended ${ }^{27}$.

What the list in college of Arms MS Arundel 48 provides, therefore, is a complete picture of the intended sizes and composition of all of the garrisons. It provides a picture of Bedford's adjustments following his return to Normandy. As we have seen, its heading refers to the issuing of new indentures. Where garrison sizes had been changed, the old sizes are also given in the list. As can be seen from Table 1, these are almost identical to those in the 1433 list. The small variations are likely to be scribal or copying errors.

It is clear that Bedford had taken an opportunity to change the sizes of garrison and to redistribute troops across the duchy, as well as to establish separate companies which were to be based in garrisons and contribute to the defence of the place but would be on permanent standby for service in the field (« pour les champs »). Twenty places saw the installation of such companies which were made up exclusively of mounted troops in a ratio of one man-at-arms to three archers. Together these troops for the field made up 1.628 (36 \%) of the total number of troops which the English held in Normandy after Bedford's reforms. The companies were intended to provide a standing army for the field. Not only would this reduce reliance on reinforcements from England but it would also ensure capacity to respond swiftly to, and even to discourage, French incursions. This was not a wholly new idea. Detachments had often been drawn from garrisons to serve at sieges or in other field activities ${ }^{28}$. But the reforms of October 1434 placed this on a more systematic basis. This indicates Bedford's intention to maintain a position of active defence.

\section{Changes and distribution}

According to the list for 1433 in Lambeth MS 506 there were 3186 troops held by the English in Normandy and the « pays de conquête » in 1433 . The list in College of Arms MS Arundel 48 gives 3188 for this period, and

26 BnF, Nouvelle acquisition française 1482/129 (order to pay, following the indenture).

27 Oxford, Bodleian Library MS Charter Foreign 314 (« quittance » dated 6 March 1435). The shortfall of seven mounted archers in the creu and temporary absences of troops led to a deduction of 131. 14 s. 6 d.t. in wages. No gains of war were made over the quarter from 29 September to 28 December.

28 A. Curry, "The Organisation of Field Armies in Lancastrian Normandy ", Armies, Chivalry and Warfare in Medieval Britain and France, Harlaxton Medieval Studies, volume VII, ed. M. Strickland, Stamford, 1998, p. 207-233. 
4527 as the total following the reforms of October 1434. However, 1628 of these were made up of the companies for the field. This figure is close to the 1600 field troops whose financing Bedford had arranged during his time in England. The regional distribution of these field companies is interesting. Almost half were concentrated along the southern frontier of Normandy. At Fresnay, for example, there had been 160 troops in 1433 ; from October 1434 there were 256, of which 160 were in the company for the field. Taking both regular garrison troops and the field companies together, we can see that $30 \%$ of the English manpower was placed along the southern frontier. This area had proved vulnerable from the late 1420s despite English tenure of Maine. Bedford intended to use the mobile companies along the southern frontier to follow up the military successes of the earl of Arundel in the area earlier in 1434 as well as to protect and extend his own interests as count of Maine and Anjou.

The second largest concentration of troops was placed by Bedford in the Vexin, such as at Gisors and Neufchatel, ending the arrangement whereby in 1433 these places were garrisoned out of local appatis and where the size of the garrison was at the behest of the captain, Sir Thomas Kyriell. Bedford hoped to extend the successes of the summer of 1434 of John, Lord Talbot towards the Beauvaisis, an area which had been lost to the French in 1429-1430. The frontier around Verneuil, Conches, Evreux and Dreux was also strengthened. Louviers had been retaken from the French in 1431 but its fortifications had been demolished, hence its omission from the list ${ }^{29}$.

More surprisingly, perhaps, few field companies were introduced into the area towards Paris, and regular garrisons in this area were mainly reduced in size. More troops were also installed in St Germain-en-Laye although the garrisons at Mantes, Meulan and Poissy were kept at must the same strength as earlier and that at Pontoise was actually decreased. By the following summer, the folly of this omission was revealed by the French advance to St-Denis. It may be that Bedford had hoped to rely on Burgundian assistance. A peak in Anglo-Burgundian cooperation had been reached in the late summer and autumn of 1433 with successful activities in Ponthieu under Robert, lord Willoughby and the comtes de St Pol and Ligny. But such assistance was lacking in 1435, and shortly after the death of Bedford, Philip, duke of Burgundy defected to the French.

Smaller numbers of field companies were placed in the south-west of the duchy. At Avranches the total size of 160 was unchanged but half the troops were to be held for the field. There was still a reasonable concentration of

29 Sir Roland Standish was guarding the town in October 1431 as its fortifications were demolished (BN manuscrit français 25770/682). The town was recaptured and refortified by the French from 1440 and proved a thorn in the flesh of the English. 
troops in this area, prompted by the decision to renew the siege of MontSaint-Michel. The list shows the plan to put 400 men into Ardevon. As it happened, a French attack in January 1435 damaged this fortification, forcing Lord Scales and his men to evacuate it. By April 1435 Scales had reassembled his men at St Jean-le-Thomas to resist the enterprises of the garrison of MontSaint-Michel ${ }^{30}$.

Very few mobile retinues were kept in the heartlands of the duchy. The 1433 list had considered many of the places there to be not at risk. It has noted that only 12 men needed to be held in Bayeuyx, for instance, since the city was well populated and the enemy supporting the Dauphin were far removed geographically from $i^{31}$. It remained at 12 men after the reforms, but the garrison at Lisieux was decreased by eight men. It is also indicative of English perceptions of security that the town garrison at Rouen was reduced from 184 to 132 men, and no field company was ordered to be held in either the Norman capital or Caen.

It is clear that to some degree Bedford had simply redistributed troops across the duchy, or had redesignated garrison troops to be in the companies for the field, as seems to be the case at Avranches. Further work on the muster rolls would not doubt reveal the extent to which individual soldiers were moved between locations ${ }^{32}$. There were relatively few changes of captaincies at this point. A comparison of the 1433 and 1434 lists reveal 10 changes, three (Gisors, St German and Château-Gaillard) relating to the appointment of John, Lord Talbot who had crossed earlier in the year with an expeditionary army, and two (Pont-de-L'Arche and St-Lô) to the earl of Arundel who had crossed under similar circumstances in May 1434. Two additional captaincies (Bayeux and Honfleur) were taken up by Bedford himself. Bedford's reforms thereby generated the largest number of multiple captaincies ever seen under English rule.

Overall, Bedford had increased the number of troops held by the English in Normandy and the "pays de conquête " by 1339 men. At just over 4500 the English military establishment may have been at its largest since the initial days of Henry V's conquest. Overall we can see Bedford's intentions to secure the defence of the duchy of Normandy by guarding and advancing its frontiers in the south and north-east. The indentures, as summarised in the list, mark an important statement of Bedford's forward planning, emphasising his desire to place the English military effort on the offensive without the need for large and costly armies from England.

30 BnF, pièces originales 2659 Scales 5 ; BnF manuscrit français 26059/2500.

31 J. Stevenson, Letters and Papers..., op. cit., II, ii, p. 541.

32 See the Norman garrison element of www.medievalsoldier.org for the database which would underpin such a study. 
Table 1. - Comparisons of sizes between the 1433 and 1434 lists.

\begin{tabular}{|c|c|c|c|c|c|}
\hline $\begin{array}{c}\text { Place/retinue } \\
\text { (order as in } 1434 \text { list) }\end{array}$ & $\begin{array}{l}\text { total } \\
1433-4 \\
\text { list }\end{array}$ & $\begin{array}{c}\text { Total } \\
\text { previous } \\
\text { size, } \\
1434 \text { list }\end{array}$ & $\begin{array}{c}\text { Total } \\
\text { new, } \\
1434 \\
\text { list }\end{array}$ & $\begin{array}{c}\text { Field } \\
\text { companies, } \\
1434 \text { list }\end{array}$ & $\begin{array}{c}\text { Regular } \\
\text { garrisons, } \\
1434 \text { list }\end{array}$ \\
\hline Falaise & 80 & 80 & 80 & & 80 \\
\hline Coutances & 40 & 48 & 32 & & 32 \\
\hline Avranches & 160 & 160 & 160 & 80 & 80 \\
\hline Vire & 80 & 80 & 108 & 60 & 48 \\
\hline Tombelaine & 96 & 96 & 96 & & 96 \\
\hline Saint-Lô & 48 & 48 & 40 & & 40 \\
\hline Carentan & 16 & 16 & 16 & & 16 \\
\hline Cherbourg & 96 & 96 & 100 & & 100 \\
\hline $\begin{array}{l}\text { Regneville inclu- } \\
\text { ding bailliage(1434 } \\
\text { old, garrison only) }\end{array}$ & 12 & 12 & 24 & & 24 \\
\hline Bayeux & 12 & 12 & 12 & & 12 \\
\hline Bailli of Caen & 26 & 0 & 26 & & 26 \\
\hline Caen & 120 & 120 & 120 & & 120 \\
\hline Verneuil & 64 & 64 & 260 & 200 & 60 \\
\hline Touques & 8 & 8 & 8 & & 8 \\
\hline Pont d'Ouve & 8 & 7 & 7 & & 7 \\
\hline Dreux & 60 & 60 & 100 & 40 & 60 \\
\hline $\begin{array}{l}\text { Tour de Danne- } \\
\text { marche/Dreux }\end{array}$ & 40 & 40 & 40 & & 40 \\
\hline Lisieux & 36 & 36 & 28 & & 28 \\
\hline Evreux & 140 & 140 & 200 & 120 & 80 \\
\hline Caudebec & 24 & 24 & 24 & & 24 \\
\hline $\begin{array}{l}\text { Rouen town, gates } \\
\text { and walls }\end{array}$ & 184 & 184 & 132 & & 132 \\
\hline Rouen bridge & 24 & 25 & 25 & & 25 \\
\hline Rouen castle & 60 & 60 & 60 & & 60 \\
\hline Conches & 40 & 40 & 68 & 40 & 28 \\
\hline Gisors & 0 & 60 & 156 & 100 & 56 \\
\hline Neufchatel & 0 & 60 & 68 & 20 & 48 \\
\hline Pontoise & 160 & 160 & 112 & 64 & 48 \\
\hline Meulan & 80 & 80 & 80 & 32 & 48 \\
\hline
\end{tabular}




\begin{tabular}{|c|c|c|c|c|c|}
\hline $\begin{array}{l}\text { Mantes including } \\
\text { bailli }\end{array}$ & 156 & 161 & 168 & 72 & 96 \\
\hline Poissy & 16 & 16 & 16 & & 16 \\
\hline $\begin{array}{l}\text { St-Germain-en- } \\
\text { Laye }\end{array}$ & 40 & 40 & 92 & 60 & 32 \\
\hline Chateau-Gaillard & 40 & 40 & 40 & & 40 \\
\hline $\begin{array}{l}\text { Arques including } \\
\text { bailli }\end{array}$ & 80 & 80 & 120 & 80 & 40 \\
\hline Alencon & 160 & 160 & 256 & 160 & 96 \\
\hline Fresnay & 160 & 160 & 256 & 160 & 96 \\
\hline $\begin{array}{l}\text { Essay and bailli of } \\
\text { Alençon }\end{array}$ & 56 & 56 & 120 & 80 & 40 \\
\hline Exmes & 40 & 40 & 52 & 20 & 32 \\
\hline Argentan & 80 & 80 & 128 & 80 & 48 \\
\hline Domfront & 120 & 120 & 152 & 80 & 72 \\
\hline Honfleur & 52 & 52 & 48 & & 48 \\
\hline Harfleur & 120 & 120 & 120 & & 120 \\
\hline Montivilliers & 0 & 0 & 0 & & 0 \\
\hline Bailli of Rouen & 26 & 26 & 26 & & 26 \\
\hline Pont-de-l'Arche & 80 & 80 & 128 & 80 & 48 \\
\hline Vernon & 80 & 80 & 48 & & 48 \\
\hline Gournay & 0 & 0 & 0 & & 0 \\
\hline Dieppe & 16 & 16 & 16 & & 16 \\
\hline $\begin{array}{l}\text { Master of } \\
\text { ordnance }\end{array}$ & 18 & 18 & 13 & & 13 \\
\hline Stanlowe treasurer & 15 & 15 & 15 & & 15 \\
\hline Stanlowe in field & 0 & 0 & 60 & & 60 \\
\hline Surreau treasurer & 0 & 10 & 10 & & 10 \\
\hline $\begin{array}{l}\text { Durant receiver } \\
\text { general }\end{array}$ & 10 & 0 & 9 & & 9 \\
\hline $\begin{array}{l}\text { Hunte controller of } \\
\text { receipt }\end{array}$ & 2 & 2 & 2 & & 2 \\
\hline $\begin{array}{l}\text { Ardevon, guard } \\
\text { and field }\end{array}$ & 0 & 0 & 400 & & 400 \\
\hline Longny, for field & 0 & 0 & 50 & & 50 \\
\hline bailli of Mantes & 25 & 0 & 0 & & 0 \\
\hline earl of Arundel & 80 & 0 & 0 & & 0 \\
\hline Totals & 3186 & 3188 & 4527 & 1628 & 2899 \\
\hline
\end{tabular}




\section{London, College of Arms MS 48 folios 274r-276 $\mathbf{v}^{33}$.}

\section{Folio 274r}

Ce sont les endentures des garnisons de Normandie et pais de conquest advisees et faictes a Rouen ou mois doctobre mil iiijc xxxiiij par monsieur le Regent estant pour lors audit lieu

Premierement a Falaise. Monsieur le Regent ij lances acheval. xviij apie et les archiers Et le temps precedent y avoit $\mathrm{v}$ lances acheval. $\mathrm{xv}$ apie et $\mathrm{lx}$ archiers

Coustances. Monsieur de Talbot. Et le temps precedent y avoit ij lances acheval. vj apie et les archiers vj lances acheval. vj apie et xxxvj archiers

Avranches. Monsieur de Souffork. Dont il y a xx lances pour les champs acheval xxij lances acheval. xviij apie Et paravant il avoit xxx lances acheval. $\mathrm{x}$ apie, et $\mathrm{vj}^{\mathrm{xx}}$ archiers

Vire. Messire Andry Ogard.

Dont il y a xv lances acheval pour les champs

Et paravant y avoit xvij lances acheval. $\mathrm{x}$ apie, et les archiers $\mathrm{x}$ lances acheval. $\mathrm{x}$ apie et $\mathrm{lx}$ archiers

Tombelaine. Mondit seigneur de Souffork. xvj lances acheval. viij apie et lxxij archiers Il y en avoit autant paravant

Saint Lo. Monsieur darundell Et paravant y avoit iiij lances acheval. viij apie et les archiers

ij lances acheval. viij apie

Carentan. Messire Nicole Bordet

Il y en avoit autant paravant

j lance acheval iij apie

Chierbourg. Monsieur le Regent.

iiij lances acheval xxj apie et les archiers Il y avoit paravant $\mathrm{v}$ lances acheval xix apie et lxxij archiers

Reneville. Hue Spencer bailli de Coustantin pour ladite place et sondit bailliage ij lances acheval. ij apie. $x x$ archiers Il y avoit paravant pour la garde de la place seulement $\mathrm{j}$ lance acheval. ij apie et les archiers

Bayeux. Monsieur le Regent Il est demoure come il estoit paravant

j lance acheval. ij apie

\section{f. $274 v$}

Le bailli de Caen

Caen. Monsieur le Regent

Il est demoure comme paravant ij lances acheval. xxiiij archiers

iij lances acheval. xxvij apie. iiij $^{\mathrm{xx}}$ archiers

33 I am grateful to the College of Arms for permission to view this text and to produce a transcript here. Thanks also to Matthew Jones, their archivist. 
Verneuil. Monsieur darundell. Lij lances acheval. xiij apie Dont il y a L lances acheval pour les champs et les archiers

Et paravant $\mathrm{y}$ avoit vj lances acheval. $\mathrm{x}$ apie et les archiers

Touque. Messire Andry Ogard. ij lances acheval et vj archiers

Autant que paravant

Pont doue. Hiere Johan. $\quad$ j lance acheval et vj archiers

Ainsi que paravant

Dreux. Messire Guillaume du Broullas. xxx lances acheval et lxx hommes de trait Dont il y a dix lances et xxx archiers qui seront pour les champs et paiez au pris des gages de Normandie. Et les autres xx lances et $\mathrm{xl}$ hommes de trait seront paiez $\mathrm{x}$ f. par mois pour homme darmes et $\mathrm{C}$ st pour homme de trait sans tiercoyer pour les dis xx lances et seront les dis xxx archiers anglois.

Et du surplus il tiercoyera pource quils ont plaines ou entiers gages

Et paravant ny avoit que xx lances et $\mathrm{xl}$ hommes de trait

Au dit lieu et pour la garde dicellui et de la Tour de Dannemarche, a la charge de messire Tassin Gaudin chevalier. $\mathrm{x}$ lances apie et $\mathrm{xxx}$ archiers

Ainsi que paravant

Lisieux. Thomas Reddugh. ij lances acheval. v apie xxj archiers

Et paravant y avoit iiij lances $\wedge$ acheval $\wedge^{\wedge}$ apie et les archiers

Evreux. Messire Robert Standish pour la garde de la place et pour le bailliage

dudit lieu

xxxij lances acheval. xviij apie et CL archiers

dont il y a xxx lances pour les champs

Et paravant $\mathrm{y}$ avoit $\mathrm{xv}$ lances acheval $\mathrm{xx}$ apie et $\mathrm{cv}$ archiers

Caudebec. Messire Jehan Robessart j lance acheval v apie et xviij archiers

Il est comme paravant

\section{f. $275 \mathrm{r}$}

Rouen. Monsieur le Regent pour la ville, portes, et murs. vj lances acheval xx apie et $\mathrm{Cvj}$ archiers

Et paravant y avoit vj lances acheval. xxiij apie et vij ${ }^{\mathrm{xx}} \mathrm{Xv}$ archiers

Pour le pont de Seine mondit seigneur le Regent $\mathrm{j}$ lance acheval iiij apie et xx archiers

Il est comme auparavant

Pour le Chastel de Rouen, mondit seigneur le Regent, ij lances acheval. xiij apie, et les archiers

Ainsi que paravant

Conches Henry Standish. xij lances acheval. v apie, et les archiers

Dont il y a x lances acheval pour les champs

Et paravant $\mathrm{y}$ avoit $\mathrm{v}$ lances acheval. $\mathrm{v}$ apie, et les archiers 
Gisors. Monsieur de Talbot. xxvij lances acheval. xij apie Dont il y a pour les champs xxv lances acheval

Et paravant $y$ avoit vj lances acheval. ix a pie et xlv archiers

Neufchastel. Messire Loys de Spoy. vij lances acheval. x apie, et les archiers

Dont il y a v lances acheval pour les champs, et les archiers

Et paravant y avoit vj lances acheval. ix apie, et xlv archiers

Pontoise. Messire Richart Merbury. xviij lances acheval. xxij apie et lxxij archiers Dont il y a pour les champs xvj lances acheval.et les archiers

Et paravant $y$ avoit $\quad x x v$ lances acheval. $x v$ apie et $v^{\mathrm{xx}}$ archiers

Meulent, Monsieur le Regent, $x$ lances acheval, $x$ apie

Dont il y a pour les champs viij lances acheval

Ainsi que paravant

Mante, messire Richart Guethin pour la garde de la ville, et le bailliage xx lances acheval xxij apie, et $\mathrm{vj}^{\mathrm{xx}} \mathrm{vj}$ archiers

Dont il y a xviij lances acheval pour les champs, et les archiers

Et paravant y avoit de Retenue ordinaire xij lances acheval. xij apie, et lxxij archiers

Et de creue qui $\mathrm{y}$ fu mise pour la seurete de la dite ville $\mathrm{x}$ lances acheval et xxx archiers

Et pour le bailliage, $\mathrm{j}$ lance acheval, et xxiiij archiers

\section{f. $275 \mathrm{v}$}

Poissy. Monsieur de Talbot. iiij lances apie, et xij archiers Ainsi que paravant

Saint Germain en Laye, mondit seigneur de Talbot xvij lances acheval. vj apie, et lxix archiers

Dont il y a xv lances acheval pour les champs, et les archiers

Et paravant $y$ avoit iij lances acheval. vij apie, et xxx archiers

Gaillart, Monsieur de Talbot. ij lances acheval. viij apie, et xxx archiers

Et paravant $\mathrm{y}$ avoit $\mathrm{v}$ lances acheval. $\mathrm{v}$ apie, et $\mathrm{xxx}$ archiers

Arques messire Jehan Montgomery pour la garde de la dite place, et pour le bailliage

de Caux ij lances acheval. viij apie, et xxx archiers Et pour les champs quil tendra a $\mathrm{Eu}$, oultre et pardessus les gens quil y doit avoir sur la revenue de la terre et comte dudit lieu de Eu xx lances acheval.

Et les archiers

Et paravant avoit seulement $\mathrm{x}$ lances acheval. $\mathrm{x}$ apie, et les archiers

Alencon. Monsieur le Regent. xliij lances acheval. xxj apie, et ix ${ }^{\mathrm{xx}}$ xij archiers

Dont il y a xl lances acheval pour les champs, et les archiers

Et paravant y avoit xxvij lances acheval. xiiij a pie, et vj ${ }^{\mathrm{jx}}$ archiers

Fresnay le Vicomte, messire Jehan Fastolf. $\quad$ xliij lances acheval. xxj apie, et $\mathrm{ix}^{\mathrm{xx}} \mathrm{xij}$ archiers Dont il y a xl lances a cheval pour les champs et les archiers

Et paravant $y$ avoit $\mathrm{xxxj}$ lances acheval ix apie et vj ${ }^{\mathrm{jx}}$ archiers 
Essay messire Guillaume Oldehall. pour la garde de la dite place et pour le bailliage ${ }^{\wedge}$ dudit lieu ${ }^{\wedge}$ dAlencon $\quad x$ xiij lances acheval. vij apie, et iiij ${ }^{\mathrm{xx}} \mathrm{x}$ archiers

Dont il y a xx lances acheval pour les champs

Et paravant il avoit vij lances acheval. vij apie, et les archiers

Exmes, messire Jehan Gray. vij lances acheval. vj apie

Dont il y a v lances acheval pour les champs et les archiers

Et paravant $y$ avoit vij lances acheval. iij apie, et xxx archiers

\section{f. $276 \mathrm{r}$}

Argenthen. Messire Richart Haryngton bailli de Caen. xxij lances acheval. x apie

Dont il y a xx lances acheval pour les champs.

Et paravant $\mathrm{y}$ avoit $\mathrm{x}$ lances acheval. $\mathrm{x}$ apie, et les archiers

Dampfront. Monsieur de Scales. xxiij lances acheval. xv apie, et les archiers

Dont il y a xx lances acheval pour les champs

Et paravant $\mathrm{y}$ avoit $\mathrm{xv}$ lances acheval. $\mathrm{xv}$ apie, et iiij $^{\mathrm{xx}} \mathrm{x}$ archiers

Honnefleu. Monsieur le Regent ij lances acheval. $\mathrm{x}$ apie, et les archiers

Et paravant $y$ avoit iij lances acheval. $\mathrm{x}$ apie, et les archiers

Harfleu. Guillaume Miners. ij lances acheval. xxviij apie, iiij ${ }^{\mathrm{xx}} \mathrm{X}$ archiers

Ainsi que paravant

Moustiervilliers Clement Owreton le garde pour iij ${ }^{c}$ f. par an.

Et ny a eu riens mue

Le bailli de Rouen pour son bailliage, ij lances acheval et xxiiij archiers

Il est comme paravant

Le Pont de 1Arche, monsieur darundell. xxij lances acheval. $x \quad$ apie et les archiers Dont il y a pour les champs xx lances acheval et les archiers de lostel de mondit seigneur dAroundell quil doit avoir pour la compaignie et estre entour sa personne

Et paravant $\mathrm{y}$ avoit audit lieu $\mathrm{x}$ lances acheval. $\mathrm{x}$ apie et $\mathrm{l}$ archiers

Vernon, messire Guillaume Lucey. ij lances acheval. $x$ apie, et les archiers

Et paravant $\mathrm{y}$ avoit $\mathrm{x}$ lances acheval. $\mathrm{x}$ apie, et les archiers

Gournay. Messire Thomas Kyriel le tient par certain traictie etc

Diepe. Messire Jehan Salvain bailli de Rouen j lance acheval. iiij apie, et les archiers Ainsi que paravant

\section{f. 276v}

Le maistre des ordonnances de Normandie j lance acheval xij archiers

Et paravant il avoit un lance acheval et xvij archiers

Jehan Stanlowe tresorier de Normandie j lance acheval xiiij archiers

Ainsi que paravant 
*Le dit Stanlowe pour aidier a conduire les finances, et server aux champs xv lances et xlv archiers

Pierre Surreau semblablement tresorier de Normandie, $\mathrm{j}$ lance acheval, $\mathrm{j}$ apie et viij archiers Ainsi que paravant

**Michiel Durant Receveur general de Normandie j lance acheval et viij archiers

Thomas Huncte contrerooleur de la Recepte generale de Normandie ij archiers Ainsi que paravant

*** La Bastide dArdevon pour la garde dicelle et pour les champs $L$ lances acheval. $L$ apie et iijc archiers

${ }^{* * *}$ Loigny Pierre Gressart pour aler aux champs $\mathrm{xx}$ lances acheval et xxx archiers

\section{Marginal annotations}

*ils sont de nouvel mis en la retenue ordinaire

**Il a este puis nagaires mis oudit office et en la retenue ordinaire

${ }^{* * *}$ Ces ij parties acouplees sont de nouvel mises en la retenue ordinaire

\section{Abstact}

\section{Key words :}


